\title{
Algumas demonstrações para introduzir a arte da performance
}

\section{CARINA SEHN}

PAOLA ZORDAN

Palavras-chave: Arte viva, história da performance, presença

\section{Resumo}

O texto traz algumas noções relativas à performance $\mathrm{a}$ partir de exemplos, alguns bastante conhecidos do público especializado, para introduzir questões básicas em torno desse tipo de manifestação, apresentando célebres obras performáticas. Pressupondo que a performance ainda não seja uma arte familiar para a maior parte das pessoas, uma breve história de suas origens e marcos principais é traçada. A intenção é mostrar como se constitui essa arte, suas relações com as intensidades do corpo e o porquê da performance ser considerada "arte viva" e não de representação. 


\title{
Some demonstrations to introduce the art of performance
}

\section{CARINA SEHN}

PAOLA ZORDAN

\begin{abstract}
The article discusses some notions related to performances parting from examples, some well-known to the specialized audience, with the intention to introduce questions around performance art, presenting some celebrated performance work. Assuming that performance art is not yet a familiar topic for most of the people, a brief history of its origins is showed. The intention is to show how this art is constituted, its connections with body's intensities and why performances are "live art" and are not considered simply representation.
\end{abstract}

Keywords:

Live art, history

of performance, presence 


\section{Algunas demostraciones para introducir el arte de la performance}

\section{CARINA SEHN}

PAOLA ZORDAN

Palabras-clave: Arte vivo, historia de la performance, presencia

\section{Resumen}

El texto trae algunas nociones relacionadas a la performance a partir de ejemplos, algunos bastante conocidos por el público especializado, para introducir cuestiones básicas sobre ese tipo de manifestación, presentando performances celebres. Suponiendo que la performance aún no es un arte familiar conocido para la mayoría de la gente, una breve historia de sus orígenes e hitos principales es esbozada. La intención es mostrar cómo se constituye ese arte, sus relaciones con las intensidades del cuerpo y el motivo por el que la performance es considerada "arte vivo" y no representación. 


\begin{abstract}
A intenção deste artigo é introduzir aspectos relevantes do conceito de performance citando alguns exemplos notórios na constituição deste campo de experimentações. O texto procura trazer aspectos gerais de acontecimentos relevantes para se pensar a performance, fazendo uma síntese de seus principais elementos constitutivos. Embora a performance exista há muitas décadas, tendo sua gênese em experiências que ocorreram há mais de cem anos, como podemos conferir nas historiografias de Jorge Glusberg e RoseLee Goldberg, no Brasil ainda é uma expressão artística compreendida por poucos, principalmente enquanto modalidade híbrida. Sem classificações peremptórias, a performance transita entre todas as modalidades artísticas do componente curricular Arte. A estratégia e as escolhas aqui desenvolvidas consideram as poucas disciplinas de performances existentes nos cursos de graduação em Artes Visuais, Audiovisual, Dança, Música e Teatro em nosso país, procurando oferecer um texto introdutório com abordagens sucintas, ainda que abertas à discussão e a outros desdobramentos.
\end{abstract}

\title{
Corpos em mostra
}

Terra Comunal - Marina Abramovic + MAI (2015) realizada de março a maio no Sesc Pompéia em São Paulo foi o mais importante evento de performance já realizado até agora no Brasil. Uma mega exposição que contou com trabalhos de quatro décadas de carreira da aclamada artista sérvia e que abordava três pontos focais: o Corpo Artista, que referia-se à presença de seu próprio corpo em suas performances; o Corpo Público, que se percebe na superação dos limites entre performer e 
público mesmo; por último, o Corpo Estudante, que propicia espaços de colaboração para artistas, pesquisadores e público, nesta exposição chamada Espaço Entre.

Além das obras de Abramovic, em Terra Comunal havia, ainda, oito obras performáticas de artistas brasileiros, selecionadas por Linsey Peisinger, assistente de Abramovic, por Paula Garcia, artista brasileira, e pela própria Abramovic. São elas: Transmutações da Carne, de Ayrson Heráclito² DNA de DAN, de Maikon K3; Preenchendo o Espaço, de Marco Paulo Rolla ${ }^{4}$; apresentadas em dias e horários específicos e, outras cinco obras de longa duração, realizadas diariamente no Sesc Pompéia durante todos os dias da exposição: Corpo Ruindo, de Paula Garcias; O Datilógrafo, de Fernando Ribeiro ${ }^{6}$; O Jardim, de Rubiane Maia7; $O$ Vínculo, de Maurício Ianês ${ }^{8}$; e Vesúvio, do Grupo Empreza ${ }^{9}$. Durante dois meses estes artistas performaram diariamente e o público podia tê-los ali ao vivo todos os dias, durante seis horas por dia.

Performar: um infinitivo, verbo que não consegue conter os múltiplos sentidos implicados na ação. Uma performance não se fecha na palavra ou título que a define. Não há um conceito fechado, seja numa performance, seja no que se entenda por performance. Pode ser intervenção, exercícios entre o corpo performático e outros corpos, manifestação, testagem de limites, exploração de espaços, interação e relações diversas entre pessoas, objetos, tempo e lugar. $\mathrm{O}(\mathrm{s})$ performer(s) é/são o(s) corpo(s) que está(ão) exposto(s). Quem performa se permite experimentar. Nem toda experiência é uma performance, mas toda performance configura experiências. Experimentar: pressuposto infinito da performance.

Uma experiência única foi proposta a estes artistas, que para se prepararem para o acontecimento inédito na vida de todos ali, passaram cinco dias em companhia de Abramovic e Linsey em um workshop chamado Cleaning The House, realizado em um sítio no interior de São Paulo, em meio à natureza. Ali, eles foram convidados a permaneceram em silêncio, jejuarem (alimentando-se com 21 amêndoas no terceiro e no quarto dias), e relacionarem-se, sem ressalvas, com a natureza. Maurício Ianês, um dos artistas convidados, em entrevista a revista Trip ${ }^{10}$ abriu o seu diário e contou alguns detalhes sobre este tempo proposto por Abramovic. Ao longo do artigo voltaremos a falar deste workshop que a artista já havia realizado em Nova York com os artistas que iriam reperformar as suas obras na exposição The Artist is Present ${ }^{11}$ (2010). 
Desde 1989, Abramovic visita o Brasil para pesquisar as pedras preciosas e a sua influência sobre o corpo. Ela começou a criar objetos os quais chamou de Transitory Objects For Human Use ${ }^{12}$ e que, são hoje, usados no seu método de trabalho. Encontramos, entre as muitas pedras "obras" na exposição: Waiting Room, que contava com um grande cristal no chão e três banquinhos para sentar e observá-lo; quatro mesas com bancos em frente e uma pedra preciosa em cima: ferro, quartzo, lápis-lazuli e quartzo-negro. Shoes for Departure ${ }^{13}$, dois sapatos gigantes de ametista para calçar e ficar imóvel, energizando-se. Havia também a Video Portrait Gallery, que apresentava catorze obras em vídeo realizadas por Abramovic entre 1975 e o início dos anos 200o. Os vídeos se concentram especificamente no rosto da artista enquanto a mesma realiza muitas ações diferentes, desde comer uma cebola, até respirar com o rosto coberto de cristais. Video Gallery apresentava vídeos de 1974 a 2010. The Abramovic Method, onde o público por duas horas e meia experimentava um pouco o treinamento performático proposto pela artista - as três posturas básicas do corpo - ficar de pé, sentar e deitar. Durante duas horas o público se dividia nas práticas de 30 minutos de duração cada: andava em câmera lenta, sentava em bancos com o espaldar cravejado de cristais, ficava de pé em frente a três pedestais com cristais localizados na cabeça, no plexo solar e no peito e deitava em uma cama com cristal localizado na glândula pineal. Tudo isto usando fones de ouvido que lhe permitia ouvir muito mais a sua própria respiração do que os barulhos externos a ela. Em Terra Comunal, o público em geral teve a oportunidade de experimentar certo estado de performance, exercitando características caras a esta maneira de fazer arte: a presença, o estado de aqui e agora, a atenção plena. Experimentou, exercitou, praticou e observou a ação de muitos artistas que diariamente realizavam as suas ações. Talvez seja este o ponto de partida para que possamos voltar no tempo e desbravarmos a história desta arte ainda tão controversa, cheia de nuances e possibilidades estéticas-éticas, agora à flor da pele, seja de quem visitou a exposição ou que somente tenha ouvido falar dela.

Levei 25 anos para ter a coragem, a concentração e o conhecimento para vir a fazer isso. Era apenas uma visão, uma ideia de que haveria arte sem qualquer objeto, somente entre artista e público... eu precisava de toda a preparação, eu precisava de todas as obras que vieram antes, elas me levavam a esse lugar (ABRAMOVIC, 2015) $)^{14}$. 


\section{Fronteiras imprecisas}

A performance, por não ter fronteiras precisas, se afirma como uma arte da presença que imiscui artes cênicas, artes visuais e outras artes possíveis. Ela está ligada ao termo live art: arte viva. Este termo visa dessacralizar a arte, tirá-la do lugar meramente estético, ilusionista, artificial dos quadros, espetáculos, esculturas e outros objetos comumente considerados "arte". Trata-se de uma arte ligada ao corpo, à presença do artista e de acontecimentos que procuram colocar a arte mais perto "da vida como ela é"; executando-a a partir dos rituais cotidianos do homem e seu modo de existir.

Carlson (2010, p. 12), baseado no contexto norte-americano, embora observe a popularidade do termo, não considera que, mesmo tendo se passado mais de cem anos desde que o lugar sacralizado das "grandes obras" de arte tenha sido amplamente discutido e seus aspectos sociais pesquisados, propostas performáticas ainda são extravagantes e polêmicas entre o público. As primeiras problematizações em torno dos conceitos de arte e do que pode vir a ser a linguagem dentro das artes se situam com Marcel Duchamp. Objetos prosaicos, como um secador de copos, um ancinho, um urinol, expostos de modo a serem vistos como esculturas, chamados readymades, provocaram uma decisiva ruptura com a tradição e forçaram uma reavaliação do que podia e devia ser considerado arte. A alegação de Duchamp, leitor de Nietzsche, pensador que concebe a vida como obra de arte, era que os artistas não deveriam ser limitados a um âmbito tão rígido de representação. Antes da intervenção provocativa de Duchamp, arte era algo feito pelo homem, tipicamente de mérito estético, técnico e intelectual, meios através dos quais expressar suas ideias e emoções (GOMPERTZ, 2013, p. 330-31). Renato Cohen (2002) no seu livro Performance como Linguagem pergunta-se: "Qual o desígnio da arte: representar o real? Recriar o real? Ou, criar outras realidades? Â medida que se quebra com a representação a performance abre espaço para o imprevisto, e portanto, para o vivo, pois a vida é sinônimo de imprevisto, de risco" (COHEN, 2002, p. 97).

Algumas pistas para o aparecimento de tais questões são encontradas ao longo da história da arte contemporânea já nos anos 50, tendo seu auge entre os anos 6o e 70. Em 1933 a escola de artes Black Mountain College recebeu 22 estudantes e nove professores da antiga Bauhaus, após o fechamento da mesma pela censura prussiana em 1932. Entre os anos de 1919 
e 1933 a Bauhaus, escola de design, artes plásticas e arquitetura, mostrava novos conceitos para a arte, numa unificação de todas as artes, numa arte total onde a performance, o figurino e outras possibilidades eram exploradas. Entre os professores da Black Mountain College estavam o artista Robert Rauschenberg, seu amigo compositor e músico John Cage e o coreógrafo Merce Cunningham. Em 1952, eles convidaram o público em geral para mais um dos saraus/happenings que os mesmos organizavam na escola. Nesta noite, além da exposição das pinturas de Rauschenberg, Cunningham dançaria e John Cage, como uma "moldura para todas as atividades que aconteciam" (GOMPERTZ, 2013, p. 335), faria do alto de uma escada uma leitura/palestra da Doutrina da Mente Universal de Huang Po, mestre zen, chinês, morto em 850 , que escreveu a Doutrina da Mente Universal e seu opúsculo Da Transmissão do Espírito, que se trata de um tratado pedagógico. Um dos trechos lidos por Cage dizia: "No Zen-Budismo nada é bom nem mau. Ou belo ou feio... A arte não deve ser diferente da vida, mas uma ação dentro da vida. Como tudo na vida, com seus acidentes e acasos e diversidade e desordem e belezas não mais que fugazes" (GOLDBERG, 2006, p. 116). Aos artistas que realizavam ações performáticas durante a leitura não havia sido oferecida nenhuma indicação de tempo para que realizassem suas atividades; - seguiu-se a desordem, enquanto Cage "palestrava" - o evento foi divertidíssimo e a arte performática dera o seu primeiro passo experimental rumo à notoriedade (GOMPERTZ, 2013, p. 335). O que se via então era um aglutinamento de várias expressões de arte como a música, as artes plásticas, a literatura, o cinema e o teatro, característica herdada desde a Bauhaus onde o termo "obra de arte total", cunhado pelo seu fundador Oskar Schlemer, era o fio condutor de todas as produções artísticas.

Em 1952, aconteceria no Maverick Hall, um dos episódios mais importantes na história da música, da performance e na carreira de John Cage. O público esperava ansioso para ouvir a mais recente obra de Cage quando o pianista David Tudor entrou em cena, sentou-se ao piano e durante quatro minutos e 33 segundos ele ficou em silêncio, imóvel, somente mexendo-se ao final deste tempo para deixar o palco. A obra intitulada por Cage de 4'33, deixou o público do teatro perplexo e bastante revoltado. Diziam que Cage havia sido desrespeitoso com uma peça que não consistia em nada senão silêncio! Cage respondeu às críticas dizendo que 4'33 não era silenciosa, que o silêncio era algo que não existia. Ele declarou que durante o primeiro 
movimento pôde ouvir o barulho do vento que soprava lá fora, seguido do tamborilar de gotas de chuva no telhado. A obra, disse, não era sobre silêncio e sim sobre audição.

Allan Kaprow, pintor e intelectual americano que havia sido aluno de composição de Cage na New School for Social Research em Nova York, "trouxe os happenings para o público em geral ver" (GOLDBERG, 2006, p. 118). Em 1959, dentro da galeria Reuben em Nova York, Kaprow realizou a sua obra 18 happenings em 6 partes $^{15}$, onde o público, que ele mesmo havia convidado através de cartas enviadas pelo correio, chegava à galeria e podia ver o seu nome constando no programa como parte do elenco. Então cada um tomava seu lugar e iniciavam-se uma série de ações comuns como subir em uma escada, sentar-se em uma cadeira ou espremer uma laranja. Estas ações levavam o público a se deslocar por três diferentes espaços separados por painéis semitransparentes e montados dentro da galeria. Tudo acontecia de forma sequencial e os performers haviam passado por duas semanas de ensaios para que tudo acontecesse dentro de um rigoroso controle. Para Kaprow, que também havia sido "aluno e pesquisado a obra de Jackson Pollock" e sua $a c-$ tion painting, era preciso remover a tela por completo e, em vez disso, "tornar-se preocupado e até deslumbrado com o espaço e os objetos da nossa vida cotidiana, quer sejam os nossos corpos, roupas ou quartos..." (GOMPERTZ, 2013, p. 337). Kaprow em seus trabalhos utilizava materiais como lâmpadas, neóns, meias velhas, um cachorro, filmes, cadeiras, comida, água etc. Ele dizia que no futuro não mais se diria "sou um pintor", "sou um poeta" ou um "dançarino" e sim, simplesmente, "sou um artista” (GOMPERTZ, 2013, p. 337). Ressaltamos que em um happenig as imagens relacionam-se com outras imagens e umas influenciam as outras, com nos diz Bergson em Matéria e Memória ao falar sobre o universo onde "tudo o que existe são imagens relacionando-se entre si infinitamente" (BERGSON, 1990, p. 9). No happening tudo é acontecimento, os performers, a ação dos performers, o lugar/espaço onde acontece a ação e o tempo que cada uma delas leva para se efetivar no corpo e na visualidade, na latitude e na longitude.

Em City Scale ${ }^{16}$, de Ken Dewey, o público se reunia numa das extremidades da cidade ao anoitecer e preenchia uma série de formulários do governo. Logo após era levado a circular pela cidade e presenciar uma série de happenings/ações performáticas em diferentes lugares: uma mulher que despia-se na janela de um apartamento, um balé de carros num esta- 
cionamento, um cantor em uma vitrine, balões meteorológicos em um parque desolado, um restaurante self-service, uma livraria e ao nascer do sol do dia seguinte chegava ao final com um vendedor de aipo em um cinema.

\section{"Como", ao invés de "o que"}

Os artistas passaram a sair dos espaços convencionais e a buscar uma experiência nova, levando o público a vivenciar o que a obra propõe e não somente a fruição da mesma de forma estática e separado dela. Ele já não é mais espectador passivo, mas agente ativo da ação, a qual já não acontece mais sem ele.

Na performance, a intenção vai passar do what para o how (do que para como). Ao se romper com o discurso narrativo, a história passa a não interessar tanto e sim, como "aquilo" está sendo feito. Essa intenção reforça uma das características principais da arte da performance e de toda a live art, que é o de reforçar o instante e romper com a representação (COHEN, 2002, p. 66).

Yves Klein, artista plástico francês, realiza em 1962 um ato extremamente importante na história da arte da performance intitulado Saut dans le vide ${ }^{17}$ (Salto no vazio). Trata-se de uma fotografia que aparentemente mostra-o pulando de uma janela, de braços abertos em direção à calçada, publicada como parte de um panfleto de Klein, o qual denunciava as expedições à lua, as quais eram consideradas por ele como arrogantes e estúpidas. Klein pesquisou o conceito de vazio em diferentes obras - um livro sem palavras, uma composição musical sem composição de fato, uma instalação em uma galeria sem objetos de arte. O vazio estava ali como um signo, como uma imagem. Klein acreditava que o vazio servia como uma espécie de zona neutra, semelhante ao nirvana para os budistas, espaço livre das influências do mundo, onde as pessoas são induzidas a concentrarem-se sobre as suas próprias sensações e não na representação delas - o que ele chamou de "Zona de Sensibilidade Pictórica Imaterial" (GOLDBERG, 2006, p. 135). Segundo Richard Schechner (2006), professor de Estudos da Performance (Performance Studies) na Tisch School of the Arts da Universidade de Nova York, prestar atenção às atividades simples executadas no agora é desenvolver uma consciência zen com relação ao nosso dia a dia, uma 
honra ao comum. "Honrar o comum é notar como se parece com um ritual à vida cotidiana, o quanto consiste-se em repetições" (SCHECHNER, 2006, s/p). Podemos pensar a performance como ritual?

O artista alemão Joseph Beuys acreditava que a arte deveria transformar concretamente a vida das pessoas: "Precisamos revolucionar o pensamento humano. Antes de mais nada, toda a revolução ocorre no interior do ser humano. Quando o homem é realmente criativo, capaz de produzir algo novo e original, ele pode revolucionar o tempo" (BEUYS apud GOLDBERG, 2006, p. 139). Foi exatamente o que ele tentou com suas ações. Em Como explicar pinturas a uma lebre morta ${ }^{18}$ (1965), Beuys, com mel e folhas secas no rosto, sentou em um canto da galeria segurando em seus braços uma lebre morta, depois de um tempo passeou com ela por toda a galeria, suas patas encostavam nos quadros expostos. Às vezes parava em frente a uma das pinturas, mostrava-a ao animal e sussurrava ao seu ouvido algo sobre o sentido da obra. "Mesmo morta, uma lebre tem mais sensibilidade e compreensão instintiva do que alguns homens, com sua obstinada racionalidade" (BEUYS apud GOLDBERG, 2006, p. 140). A performance durou três horas e em nenhum momento Beuys se dirigia à plateia ou reconhecia a sua presença, o que deixava mais claro ainda a crítica que fazia o artista. "A performance, como um código secreto, contem rituais invisíveis atrás de rituais visíveis" (GLUSBERG, 2011, p. 118).

O que não se pode identificar assombra, apavora e para isto imediatamente se procura dar nome, a fim de que o inominável da experiência possa ser classificado e enquadrado na linguagem. A linguagem insere a vida na normalidade dominante das imagens já conhecidas. Saber ser um ser diferente em si mesmo, único, constituído de caos e diferença, está além das possibilidades do homem que tem vontade de verdade, como diz Nietzsche (2009). O homem é moralizado desde que nasce, pois já nasce sob uma luz branca - a luz da transcendência, do que é superior -, a linguagem que tudo organiza e mantém funcionando a vida conforme as leis da ciência. $\mathrm{O}$ homem que necessita de uma verdade cria para si as mais variadas referências visuais, os mais variados ideais. Ele encontra-se longe da terra, num lugar rarefeito, quase suspenso por uma corda, sufocado e regulado. Toda a liberdade cultivada desde os saraus do Black Mountain College, culmina então com uma arte que é uma arma de guerrilha perante a obsolescência das Belas Artes, uma "máquina de guerra", 
como diriam Deleuze e Guattari (1997), cujas forças surgem inesperadamente, fazendo sentir sua estranha presença e desaparecendo em seguida. A ação performática é radical por natureza. "A performance como verdadeira emergência estética é uma transgressão dentro de uma cultura em que o corpo, a partir das convenções vigentes, é alienado de si próprio". (GLUSBERG, 2011, p. 100). Ela não está presa ao mercado, até porque por ser uma arte que se baseia na presença do artista para ser executada, como pode ela preencher os quilômetros de paredes brancas de uma galeria de arte?

Marina Abramovic, como já apresentamos anteriormente, trabalha com performance desde o final dos anos $60 \mathrm{e}$, em 2010, a artista foi convidada a realizar uma retrospectiva da sua trajetória no Museu de Arte Moderna (MoMA) em Nova York. Convite que se torna um grande desafio a um artista do corpo, da ação. Como ela não poderia estar presente ao mesmo tempo realizando as suas ações performáticas nas várias salas de um dos maiores museus de arte contemporânea do mundo, Abramovic treinou ${ }^{19}$, por três meses, em sua casa no campo, vários artistas de performance para reapresentarem as suas performances, pois ela mesma estaria apresentando no MoMA uma obra inédita, criada especialmente para a exposição: The Artist is Present (2010). Nesta, a artista durante os três meses de exibição, sentar-se-ia diariamente em uma cadeira com uma mesa à sua frente e mais uma cadeira vazia na ponta da mesa, nesta sentaria o público, uma pessoa de cada vez. A performance durava diariamente 6 hзomin, que era o tempo de abertura do museu. Abramovic não levantava nem mesmo para fazer xixi, a sua cadeira continha uma espécie de reservatório no assento, para que a artista sem se levantar pudesse urinar ali mesmo. Os visitantes podiam sentar-se a sua frente e olhar para ela pelo tempo que quisessem e assim faziam parte da obra de arte. A maioria das pessoas que formavam filas quilométricas contornando os quarteirões do museu permanecia na presença da artista pelo tempo de um a dois minutos e outros ficavam por horas ali, tiveram dois visitantes que permaneceram em frente à Abramovic até o final do dia, para desespero das pessoas que aguardavam silenciosamente na fila. A indicação para participar da performance era simples: tinha-se que permanecer em silêncio e imóvel do começo ao fim, assim como a artista. A retrospectiva de Marina Abramovic foi uma das mais importantes exibições que o MoMA já apresentou, tanto pelo número de pessoas que frequentaram o museu quanto pela repercussão que obteve na mídia. 


\section{Arte presente}

A arte da performance ganha status no mercado da arte contemporânea. No entanto, não deixa de ser política, provocante e polêmica, pois como é que se compra uma das obras presenciais de Abramovic, as quais abrem mão de quaisquer objetos, mas não do próprio corpo e presença da artista? O que se pode comprar na sua última obra The artist is presente? O que se leva dali senão o que se viveu, experimentou estando ali em frente à artista, na sua presença, olhando-a no olho? A performance dentro de um museu de arte, com todo o glamour, status e críticas que este acontecimento contém, mas ao mesmo tempo ela manteve a força, a imponência, a provocação plena de músculos e sangue do corpo da artista. Contendo sim um estranhamento para quem a experienciava (basta ver as fotos das expressões dos visitantes e o noticiário da televisão americana durante a exposição). Serve, definitivamente, de uma abertura para um novo lugar para o pensamento, para a emoção dentro da arte. Abramovic pode sim ter cedido às exigências do mercado, mas não deixa de fazer o que se propõe desde o início da sua trajetória: estar viva perante os olhos de quem a vê.

Richard Schechner (2006), em seu artigo O que é performance?, disserta sobre as variadas possibilidades que temos de nos relacionarmos com a performance. Segundo o professor da Tisch, um artista pode viver "sendo" a sua performance, pode estar "fazendo" a sua performance, pode "mostrar fazendo" e "pode explicar mostrar fazendo". "Sendo" a sua performance a existência por ela mesma, quando um artista já não separa mais a sua arte da sua vida, como diz Allan Kaprow, "arte como a vida". Tehching $\mathrm{Hsieh}^{20}$ é um exemplo deste modo de fazer performance. Ao longo da sua vida realizou performances longas que duravam um ano cada uma delas. Se chamavam One Year Performance e consistiam sempre de um statement que continha todas as "regras" da performance assinada por ele. Hiseh vivia a sua proposição durante todos os 365 dias do ano, ininterruptamente "in action". Na One Year Performance 1980-1981 ${ }^{21}$, iniciada em 11 de abril de 1980 e concluída em 11 de abril de 1981, o artista raspou o seu cabelo e instalou uma máquina de 'cartão ponto' em seu atelier e de uma em uma hora filmava-se ao lado da máquina. Depois mandou revelar frame a frame as imagens e preencheu muitas paredes de galeria com seus autorretratos. O resultado é um filme que mostra a passagem do tempo no relógio e na apa- 
rência do artista. Em outra performance intitulada One Year Performance 1981-1982, iniciada às 14 h do dia 26 de setembro de 1981 e encerrada às $14 \mathrm{~h}$ do dia 26 de setembro de 1982 , o artista morou na rua e não poderia dormir em nenhum lugar coberto, ou dentro de um carro, ou dentro de alguma construção, teria que ficar na rua somente com um saco de dormir. Em One Year Performance 1983-1984, iniciada em 4 de julho de 1983 e finalizada em 4 de julho de 1984, o artista em colaboração com outra artista, Linda Montano, viveu ligado a ela por uma corda de oito metros presa na cintura dos dois. Eles viviam juntos, nunca sozinhos, no mesmo quarto, em camas diferentes. Quando saíam para a rua estavam da mesma forma juntos em todos os lugares. Enfim, a vida passa a ser vivida a partir de uma proposição performática e não de outro modo.

Quando Schechner (2006) refere estar "fazendo" uma performance, ele trata de uma das características mais marcantes nesta arte. Na sua grande maioria, os artistas de performance fazem uma ação, realizam uma tarefa (task). Tendo em vista que estamos sempre fazendo algo, mesmo os que nada fazem estão fazendo algo, pois o universo é pleno de movimento, de agir, de ação, nada está parado. Podemos pensar em muitos artistas, um deles em especial é Vito Aconcci, que em sua obra Se$e^{e d b e d}{ }^{22}$ (1972), construiu na Sonnabend Galery, em Nova York, uma rampa baixa de madeira que se confundia com o chão e dava acesso à exposição. "Escondido" embaixo da rampa o artista se masturbava a partir dos passos dos visitantes que passavam pela rampa, enquanto falava em um microfone suas fantasias sobre os desconhecidos corpos que moviam-se acima dele:

você está na minha esquerda, você está se afastando, mas eu estou empurrando meu corpo contra você, no canto... você está dobrando a cabeça para baixo, em cima de mim, eu estou pressionando meus olhos em seu cabelo... eu estou fazendo isso com você agora... você está na fonte de mim... eu tenho que continuar durante todo o dia - cobrir o chão com o esperma, semente no chão... você pode reforçar a minha excitação, servir como um meio. a semente plantada no chão é o resultado conjunto da minha presença e da sua (JONES, 200o, p. 117).

Aconcci realizava uma simples ação, comum a todos os homens, não? Uma ação cotidiana que colocada como centro da ação do artista se tornara uma das mais impactantes e irônicas obras da história da performance. 
Na performance há uma acentuação muito maior do instante presente, do momento da ação (o que acontece no tempo "real"), isso cria a característica de rito com o público, não sendo só espectador, e sim, estando numa espécie de comunhão (COHEN, 2002, p. 97).

"Mostrar fazendo" é outra possibilidade de ação performática, na qual o artista desempenha uma ação e aponta para algo, sublinha algo, exibe algo - fazendo. Neste caso, não podemos deixar de citar o trabalho da perita policial e artista paraense Berna Reale, que realiza performances que oferecem um alto nível de complexidade. Em Ordinário ${ }^{23}$ (2013), por exemplo, ela aparece recolhendo e transportando cerca de quarenta ossadas de vítimas anônimas de homicídios na área metropolitana de Belém do Pará. A performance foi filmada no violento bairro de Jurunas. Tais restos mortais, de pessoas dadas como desaparecidas, geralmente são encontrados por agentes policiais em cemitérios clandestinos e levados para depósitos, diante da ausência de reclamação de exames de DNA. A coloração e a forma dos ossos podem indicar o sexo, a idade e o tempo de falecimento da vítima. Para usar esse material foi necessário um minucioso trabalho de limpeza e catalogação com a ajuda de um biólogo, posto que, após a performance, as ossadas retornaram aos depósitos para permanecerem por mais alguns anos antes de serem enterradas para sempre pela polícia. Berna mostra, conforme aponta Glusberg, "numerosos fantasmas psicológicos e sociais" que colocam em crise a estabilidade do sujeito ao romper com a "repetição normalizada de convenções gestuais e comportamentais" (GLUSBERG, 2011, p. 65). Com sua ação, Berna nos aponta algo, nos faz ver o que nem mesmo pensamos ser possível. Ela está carregando as ossadas em cima de um carrinho de mão pelo bairro de Juruna enquanto é filmada, no entanto, nem precisamos dizer que dentro desta ação estão contidas $n$ possibilidades, múltiplas potências, contínuos de variações.

Já quando Schechner (2006) se refere o modo de "explicar mostrar fazendo", ele está evidenciando os estudos performáticos. Esta investigação é um exemplo, tentamos "explicar" a arte da performance a partir de uma pesquisa prática onde a autora é também performer e busca um modo particular de se relacionar com a arte e seus variados desdobramentos. Aqui, buscamos trazer alguns modos de se fazer performance a partir dos exemplos de Schechner (2006), o que não quer dizer que neste exato momento não esteja sendo produzido/cria- 
do outro modo. A performance não para jamais de produzir a si, como uma máquina de guerra das artes quer mostrar, demo(N)strar o novo, experienciar as heterogeneidade do que que está por vir, dos fluxos, ela se "opõe ao estável, ao eterno, ao idêntico, ao constante" (DELEUZE; GUATTARI, 1997, p. 25). Deleuze, em uma entrevista a Arnaud Villani, diz que "monstro é um ser composto, que tem um segundo sentido: alguma coisa ou qualquer um cuja extrema determinação deixa plenamente subsistir o indeterminado". No rastro de Deleuze é possível pensar o que há de indeterminado também na performance, algo de monstruoso que perturba quem a vê e vivencia, um limiar de caos.

O delírio e a performance são fenômenos estreitamente relacionados. A arte não tem nenhuma relação com o "bom senso" ou com o "senso comum", para dizer com todas as letras: a arte não tem nenhuma relação com o sentido (GLUSBERG, 2011, p. 124).

\section{Sentidos caósmicos}

Se pensarmos o conceito de sentido aqui, nos é possível deixar claro que o sentido para a performance nada tem a ver com uma significação, com um significado, com uma essência, mas sim com um efeito, "um efeito produzido, cujas leis de produção devem ser descobertas” (DELEUZE, 2006, p. 177). Este sentido é produzido por certa maquinaria, com efeito físico, assignificante; por "todas as espécies de máquinas que estão entre a complexidade e o caos" (GUATTARI, 2012, p. 127), que buscam reconciliar o caos com a vida no corpo, com o acontecimento. A noção de sentido aqui é uma "contestação absoluta, uma crítica absoluta, e também de uma determinada criação" (DELEUZE, 2006, p. 177), que o quer não como predicado, como propriedade, mas como acontecimento, como uma nova realidade, como uma sutileza que ora está no corpo, ora na natureza, na Terra, no grito, nas nuvens, aqui bem dentro do estômago, dobrando-se, efetuando-se diferente e provido de uma estrutura problemática sempre aberta ao virtual - o qual não tem compromisso com a realidade, mas sim com a experimentação de si e da sua existência, com o seu processo de engendrar-se sempre novo, integrado e cósmico.

Numa perspectiva esquizoanalítica, é possível pensar a ação performática como ocupação de território, a expandir-se como grama, rizoma, sempre valendo-se do corpo e de suas 
variações contínuas. Ela acontece no espaço, metamorfoseando corpos e entorno a partir das afecções que lhe acontecem, aberta para o que a transborda. Efêmera, revolucionária, experimentadora, a performance sempre opera uma micropolítica. Como os nômades, perambula, se reveza em si mesma, equilibra suas forças e dissipa a sua energia condensada em imagens-processo que avançam progressivamente sobre quem vê, velozes e não pesadas. A performance aproxima o corpo da vida, da singularidade da vida. Ela põe em contato com o que se desconhece, com o que não está dado. Na performance, não há sujeito, este fica borrado porque está imerso na vida, em um processo de subjetivação ético-estético que se distingue de toda a moral, de todos os códigos da moral, pois cria outros estilos de vida. A performance oferece um corte mais profundo da realidade (DELEUZE, 1990, p. 62). O performer subjetiva-se ao realizar a performance, dobra-se sobre si mesmo, sobre a sua singularidade-acontecimento - sem sujeito - "um vento, uma atmosfera, uma hora do dia, uma batalha" (DELEUZE, 1992, p. 143), algo que viu na rua, a morte de um amigo, uma nova medida econômica, etc... O performer se volta para as intensidades, para as virtualidades e deixa de lado todas as formas da identidade, produz multiplicidades, que não dizem mais respeito a um único e sedentário sujeito, a um número.

\section{Irrepetível}

Ao longo da história da performance, muitas obras e artistas somente nos deixaram com as imagens das suas ações, por estas nunca mais serem reapresentadas, como por exemplo o brasileiro capixaba Marcus Vinícius na performance $O \mathrm{im}$ previsível, o acaso e o que não se sabe ${ }^{24}$ (2011); a cubana Ana Mendieta em Sin titulo (señales de sangre) 25 (1974); o americano Chris Burden em Shoot ${ }^{26}$ (1971); o alemão Bas Van Ader em Fall 1 \& $2^{27}$ (1970); Berna Reale em Palomo ${ }^{28}$ (2013), a maranhense radicada em São Paulo; Elen Gruber em O peso ( $d a$ série os 12 trabalhos) ${ }^{29}$, entre outros. O que o público em geral aprecia das performances são as suas imagens, seus registros visuais e audiovisuais, o que quer dizer que a imagem assume aqui um papel fundamental à performance. Apesar de imensurável e extemporânea, enquanto acontecimento que começa sempre na nossa pele e músculos, o que resta de uma performance é a imagem que a registrou. A imagem afirma o 
lugar do acontecimento performático para quem nunca poderia estar presente no momento da ação.

A performance apresenta, segundo Auslander (2006), professor da School of Literature, Media and Communication, uma relação ontológica com a sua documentação; pois afinal: "o espaço do documento (fotografia ou vídeo) se torna, muitas vezes, o único espaço no qual a performance ocorre" (AUSLANDER, 2006, p. 4). No caso da performance, é a imagem que também se faz performática, ou melhor, faz ver a performance que não é vista na hora da sua execução. Existem trabalhos em performance que são realizados exatamente para serem registrados, o que quer dizer que o seu registro deixa de ter um caráter simplesmente representacional, ele passa a ser objeto de arte, ele passa a guardar em si, a simbolizar a obra de um artista do corpo. Por isso podemos dizer que uma performance não pode ser exatamente reproduzida, mesmo que sua proposta seja repetida, a singularidade consegue apenas ser registrada. $\mathrm{O}$ corpo se encontra como um todo ali, uma máquina de criação, um modo de existir e de expressar-se imbricado em uma série de relações possíveis entre quem está por ali passando, quem permanece para ver e mesmo quem registra a obra.

$\mathrm{O}$ artista de performance está interessado em produzir uma imagem tão potente que seja capaz de causar em quem vê uma transformação no seu modo de existir. Dessa imagem surge uma infinidade de possibilidades a serem vistas e observadas pelo público. O performer não reproduz o mesmo. Ele recria, e as imagens oferecem outros modos de performatividade, pode-se perceber e ver coisas e elementos que muitas vezes enquanto se performa não são percebidos. Quando se performa, não mais se representa nada, não faz sentido ser idêntico a nada, buscar um personagem, uma imagem fora de si. A imagem tem vivacidade, intensidade, assume outros modos de existir para além da ação. Faz com que performances autônomas ganhem outros territórios que abrangem lugares outros daqueles por onde o corpo esteve ou experimentou. A imagem performática nada tem a ver com um índice remissivo, pois ela carrega forças corpóreas, fluxos de intensidades e ares de performance, contudo, não está apenas atrelada a uma lógica temporal e histórica, se torna extemporânea, tempo puro, movimento, cosmos. De fato, a performance projeta-se na esfera social e depois regressa em direção à própria subjetividade, já outra. Ela força a pensar primeiramente o performer 
e em seguida exige do pensamento de quem a vê. Faz brotar em nós o milésimo diferencial, a diferença intensiva. Porque quando se performa, não mais se representa nada, não faz sentido ser idêntico a nada, buscar um personagem, fazer uma cena, uma imagem fora de si.

A ação performática pretende oferecer resistência a todo o tipo de limite, de obstáculo à liberdade da criação. O performer não se fixa em nenhuma linguagem, pois a performance não precisa se definir como uma linguagem, mas sim como um espaço possível, um lugar para novas ideias, uma experiência que transforme em primeiro lugar quem a realiza e depois quem entra em contato com ela. Mesmo sob rígido treinamento, movimentos involuntários respondem aos acontecimentos que perpassam o corpo performático preparado às mais duras resistências físicas e emocionais. $\mathrm{Na}$ aclamada ação The Artist is Present, a reação de Marina Abramovich quando Ulay, seu companheiro de performances nos anos 1970 , senta à sua frente ${ }^{30}$, mostra que mesmo os preparos mais ascéticos não controlam certas emoções. Entre 736 horas e trinta minutos de performance há uma notável quebra de continuidade quando Marina é surpreendida por Ulay, fato notório que inspirou a canção "Ulay Oh", em vídeo que se tornou viral na internet ${ }^{31}$. A experiência performática oferece um novo entendimento para o próprio performer sobre o seu corpo e sua realidade. Ela demonstra que a consciência não está separada das suas mãos muito menos do seu pulmão, que se expande e se recria. $\mathrm{O}$ corpo que pulsa e respira vive. Arte e vida não se distinguem para o artista e o público entregue à experiência provocada por uma performance.

\section{NOTAS}

1. “Terra Comunal" do latim significa 'terra comum'. Realizada no e pelo Sesc Pompéia de São Paulo nos meses de março a maio de 2015.

2. Disponível em: <https://www.youtube.com/watch?v=LDkKj-hgvcU>. Acesso em: 18 jul. 16.

3. Disponível em: <https://www.youtube.com/watch?v=bWf9PQW2EDo>. Acesso em: 18 jul. 16.

4. Disponível em: <https://www.youtube.com/watch?v=EviLPRsK2CA >. Acesso em: 18 jul. 16.

5. Disponível em: <https://www.youtube.com/watch?v=HtzKxztIBpA>. Acesso em: 18 jul. 16.

6. Disponível em: <https://www.youtube.com/watch?v=QSvsaogq5wk>. Acesso em: 18 jul. 16. 
7. Disponível em: <https://www.youtube.com/watch?v=pj7iPio5nag>. Acesso em: 18 jul. 16.

8. Disponível em: <https://www.youtube.com/watch?v=fY2u59QdKKs>. Acesso em: 18 jul. 16.

9. Disponível em: <https://www.youtube.com/watch?v=bw2Wj8z5Fxg>. Acesso em: 18 jul. 16.

10. Disponível em: <http://revistatrip.uol.com.br/revista/242/reportagens/ mauricio-ianes-conta-como-foi-o-retiro-que-fez-com-marina-abramovic. html>. Acesso em: 02 set. 2015.

11. Disponível em: <https://www.youtube.com/watch?v=ASS7xMOM1EE>. Acesso em: 18 jul. 16.

12. Objetos Transitórios para Uso Humano - feitos de pedra, ervas, madeira e espelhos, são objetos que propõem uma experiência ao público, quando este se relaciona com os objetos. Este trabalho de Abramovic lembra muito o trabalho de Lygia Clark e seus "objetos relacionais".

13. Disponível em: <http://www.art21.org/images/marina-

-abramovi\%C4\%87/shoes-for-departure-1991>. Acesso em: 18 jul. 16.

14. Frase que compunha a exposição “Terra Comunal” no SESC Pompéia em São Paulo (2015), programa da exposição.

15. Disponível em: <http://www.medienkunstnetz.de/works/18-happenings-in-6-parts/>. Acesso em: 17 jan. 2017.

16. Não existem imagens disponíveis desta performance.

17. Disponível em: <https://en.wikipedia.org/wiki/File:Le_Saut_Dans_le_ Vide.jpg $>$. Acesso em: 17 jan. 2017.

18. Disponível em: <https://www.youtube.com/watch?v=Mo47lqk_QHo>. Acesso em: 17 jan. 2017.

19. O treino ou workshop que a artista chamou "Cleaning the house" consistia em variadas proposições da artista, desde passar uma noite na floresta, entrar nu no rio gelado, andar segurando um espelho de rosto na floresta, etc. Pode-se conferir trechos e a própria artista explicando sobre o workshop. Disponível em: <http://www.moma.org/interactives/exhibitions/2010/marinaabramovic/retreat_participants.html>. Acesso em: 02 set. 2015.

20. Site do artista. Disponível em: <http://www.tehchinghsieh.com>. Acesso em: 02 set. 2015.

2. Entrevista com Teching Hsieh. Disponível em: <http://www.youtube. com/watch?v=9oizVR2Kipo $>$. Acesso em: 02 set. 2015 .

22. Disponível em: <http://www.moma.org/collection/works/109933>. Acesso em: 18 jul. 16.

23. Disponível em: <http://dasartes.com.br/pt_BR/materias/ed-30-out-2013-berna-reale-moca-com-brinco-de-perola>. Acesso em: 18 jul. 16.

24. Disponível em: <https://www.youtube.com/watch?v=tTtB5LzFBGc>. Acesso em: 05 set. 2015.

25. Disponível em: <https://www.youtube.com/watch?v=JE5u3ThYyl4>. Acesso em: 07 set. 2015.

26. Disponível em: <https://www.youtube.com/watch?v=JE5u3ThYyl4>. Acesso em: 07 set. 2015. 
27. Disponível em: <https://www.youtube.com/watch?v=8loz4lHZxwk>. Acesso em: 07 set. 2015.

28. Disponível em: <https://www.youtube.com/watch?v=_Acp4cclG_A>. Acesso em: 07 set. 2015 .

29. Disponível em: <https://vimeo.com/90038040>. Acesso em: o7 set. 2015.

3o. Disponível em: <https://www.youtube.com/watch?v=sLbFugaFyAA >. Acesso em: 05 set. 2015.

31. Disponível em: <https://www.youtube.com/watch?v=hbUKUKkM77o>. Acesso em: 05 set. 2015.

\section{Referências}

ABRAMOVIC, Marina. In:Abramovic Method. Disponível em: $<$ http://mai.art/terra-comunal>. Acesso em: 17 jan. 2017. AUSLANDER, Philip. The Performativity of Performance Documentation. Performing Arts Journal, n. 84, 2006, p. 1-10. In: Performatus, São Paulo, ano 2, n. 7 Nov/2013. ISSN 2316-8102. Disponível em: <http://homes.lmc.gatech. edu/ auslander/publications/28.3auslander.pdf>. Acesso em: 17 jan.2017.

BERGSON, Henri. Matéria e Memória. Tradução Paulo Neves da Silva. São Paulo: Editora Martin Fontes, 1990.

CARLSON, Marvin. Introdução crítica aos Estudos da Performance. Belo Horizonte: Editora UFMG, 2010.

COHEN, Renato. Performance como Linguagem. São Paulo: Editora Perspectiva, 2002.

DELEUZE, Gilles. Cinema II - Imagem-Tempo. Tradução Eloisa de Araujo Ribeiro. São Paulo: Editora Brasiliense, 1990. . Conversações. Tradução Peter Pal Pelbart. São Paulo: Editora 34, 1992. . A Ilha Deserta. Organização e Tradução Luiz Orlandi. São Paulo: Iluminuras, 2006. ; GUATTARI, Félix. Mil Platôs. Vol.5. 2. ed. São Paulo: Editora 34, 1997.

GLUSBERG, Jorge. A Arte da Performance. 2. ed. São Paulo: Perspectiva, 2011.

GOLDBERG, RoseLee. A Arte da Performance. Do Futurismo ao Presente. Tradução Percival Panzoldo de Carvalho. São Paulo: Martins Fontes, 2006.

GOMPERTZ, Will. Isto é Arte?: 150 anos de arte moderna do impressionismo até hoje. Tradução de Maria Luiza X. de A. Borges. Rio de Janeiro: Zahar, 2013. 
GUATTARI, Félix. Caosmose. Tradução Ana Lúcia de Oliveira e Lúcia Cláudia Leão. São Paulo: Editora 34, 2012.

JONES, Amelia. Survey: body, splits. In: WARR, Tracey (Ed.). The Artist's Body. Londres: Phaydon, 2000.

NIETZSCHE, Friedrich. Genealogia da Moral. Tradução Paulo César de Souza. São Paulo: Cia das Letras, 2009.

REVISTA DAS ARTES. Rio de Janeiro: Editora O Selo, ano 5, n. 30, Bimestral, out./nov. 2013.

SCHECHNER, Richard. O que é performance? In: Performance studies: an introduction, second edition. New York/ London: Routledge, 2006.

Recebido em: 18/11/15

Aceito em: 27/06/16

\section{CARINA SEHN}

carinasehn@gmail.com

É mestra em Educação, Bacharela em Teatro e Especialista em Saúde Mental Coletiva. Professora do Departamento de Dança da Universidade de Caxias do Sul (UCS), pesquisa o corpo performático, a imagem e os processos vivos da natureza.

\section{PAOLA ZORDAN \\ paola.zordan@gmail.com \\ É Doutora e Mestra em Educação, Bacharela em Desenho e Licen- ciada em Educação Artística. Professora do Departamento de Artes Visuais da Universidade Federal do Rio Grande do Sul (UFRGS), pesquisa epistemologia das artes e historiografia do corpo. $\mathrm{Na}$ mesma instituição é professora do Programa de Pós-Graduação em Educação (PPGEDU/UFRGS).}

